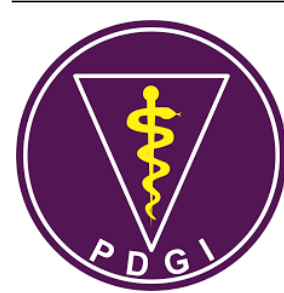

\title{
Titanium Dioxide Addition to Heat Polymerized Acrylic Resin Denture Base Effect on Staphylococcus aureus and Candida albicans
}

\author{
Dwi Tjahyaning Putranti ${ }^{1}$, Afrina Fadilla ${ }^{1 \S}$ \\ ${ }^{1}$ Department of Prosthodontics, Faculty of Dentistry, University of North Sumatera, Indonesia
}

Received date: August 18, 2018. Accepted date: September 21, 2018. Published date: October 19, 2018

\section{KEYWORDS}

denture base;

heat polymerization acrylic

resin;

Staphylococcus aureus;

Candida albicans;

Titanium dioxide

\begin{abstract}
Introduction: Heat-polymerized acrylic resin is used to manufacture almost all denture bases. One of the disadvantages of acrylic resin is its porosity and surface roughness; food scraps attach easily. If the dentures are not cleaned, they become a place for microbial species development and cause denture stomatitis, with Staphylococcus aureus and Candida albicans as the major etiologic agents. Adding nanoparticles of titanium dioxide to heat-polymerized acrylic resin may provide antimicrobial activity to the acrylic resin base. Objectives: This study aimed to determine whether adding $\mathrm{TiO}_{2}$ nanoparticles to heat-polymerized acrylic resin denture base materials affected the amounts of Staphylococcus aureus and Candida albicans. Methods: The samples in this study used heat-polymerized acrylic resin without the addition of $\mathrm{TiO}_{2}$ nanoparticles and with the addition of $2 \%, 3 \%$, and $4 \% \mathrm{TiO}_{2}$ nanoparticles on test bar sizes of $10 \mathrm{~mm} \times 10 \mathrm{~mm} \times 1 \mathrm{~mm}$. There were 48 total test samples: 24 of Staphylococcus aureus and 24 of Candida albicans. The obtained data were analyzed by a one-way ANOVA test. Results: The results showed that adding $\mathrm{TiO}_{2}$ nanoparticles influenced the amount of Staphylococcus aureus $(\mathrm{p}<0.05)$ and Candida albicans $(\mathrm{p}<0.05)$. A least significant difference test showed differences of effect in the amounts of Staphylococcus aureus when $\mathrm{TiO}_{2}$ concentrations of $2 \%, 3 \%$, and $4 \%$ were added to heat-polymerized acrylic resin denture base and there were differences in effect to amounts of Candida albicans when $\mathrm{TiO}_{2}$ concentrations of $2 \%, 3 \%$, and $4 \%$ were added to heat-polymerized acrylic resin denture base. Conclusion: Adding $\mathrm{TiO}_{2}$ nanoparticles to heat-polymerized acrylic resin denture base material affects the amounts of Staphylococcus aureus and Candida albicans.
\end{abstract}




\section{KATA KUNCI}

basis gigi tiruan; resin akrilik polimerisasi panas; Staphylococcus aureus; Candida albicans; titanium dioksida

\begin{abstract}
ABSTRAK
Pendahuluan: Resin akrilik polimerisasi panas (RAPP) digunakan dalam pembuatan hampir semua basis gigi tiruan. Salah satu kerugian dari RAPP ini yaitu porositas dan kekasaran permukaan yang cukup tinggi sehingga sisa makanan lebih mudah melekat. Apabila tidak dibersihkan dapat menjadi tempat berkembangnya spesies mikroba dan menimbulkan denture stomatitis dengan Staphylococcus aureus dan Candida albicans sebagai agen etiologi utama. Penambahan nanopartikel untuk RAPP dapat memberikan aktivitas antimikroba untuk basis resin akrilik. Tujuan: Penelitian ini bertujuan untuk mengetahui apakah penambahan nanopartikel $\mathrm{TiO}_{2}$ pada bahan basis gigi tiruan RAPP berpengaruh terhadap jumlah Staphylococcus aureus dan Candida albicans. Metode: Sampel pada penelitian ini menggunakan RAPP tanpa penambahan nanopartikel $\mathrm{TiO}_{2}$ dan dengan penambahan nanopartikel $\mathrm{TiO}_{2}$ konsentrasi $2 \%, 3 \%$ dan 4\% dengan ukuran batang uji $10 \mathrm{~mm}$ x $10 \mathrm{~mm}$ x 1 mm. Jumlah total sampel sebanyak 48 sampel yang terdiri dari 24 sampel uji jumlah Staphylococcus aureus dan 24 sampel uji jumlah Candida albicans. Kemudian, data dianalisis dengan uji Anova satu arah. Hasil: Hasil penelitian ini menunjukkan bahwa ada pengaruh penambahan nanopartikel $\mathrm{TiO}_{2}$ terhadap jumlah Staphylococcus aureus $(\mathrm{p}<0,05)$ dan Candida albicans $(\mathrm{p}<0,05)$. Uji LSD menunjukkan bahwa ada perbedaan pengaruh penambahan $\mathrm{TiO}_{2}$ dari konsentrasi $2 \%, 3 \%$ dan $4 \%$ pada bahan basis gigi tiruan RAPP terhadap jumlah Staphylococcus aureus maupun jumlah Candida albicans. Kesimpulan: Dari hasil penelitian ini dapat disimpulkan bahwa ada pengaruh penambahan nanopartikel $\mathrm{TiO}_{2}$ pada bahan basis gigi tiruan RAPP terhadap jumlah Staphylococcus aureus dan Candida albicans.
\end{abstract}

\section{PENDAHULUAN}

Kesehatan mulut adalah keadaan rongga mulut termasuk gigi geligi serta jaringan-jaringan pendukungnya yang bebas dari penyakit dan jaringan pendukung berfungsi secara optimal. ${ }^{1}$ Banyak mikroflora normal pada rongga mulut manusia karena mukosa rongga mulut merupakan habitat mikroorganisme yang baik, rongga mulut dapat memberikan lingkungan ekologi yang mendukung untuk kolonisasi mikroba. ${ }^{2}$ Beberapa mikroorganisme seperti Staphylococcus aureus dan Candida albicans dapat ditemukan pada rongga mulut tetapi sebagai komensal (normal). Belakangan ini peneliti mengemukakan bahwa pada dewasa sehat terdapat kolonisasi Staphylococcus aureus antara 24\% sampai 36\%, sementara jumlah Candida albicans yang hidup dalam rongga mulut yang sehat adalah sekitar 17,7\%.3,4 Resiko infeksi atau kolonisasi Staphylococus aureus dan Candida albicans cenderung meningkat karena faktor predisposisi seperti oral hygiene yang buruk, imunosupresi, defisiensi nutrisi, penggunaan antibiotik jangka panjang atau terapi radiasi, pemakai gigi tiruan, penderita diabetes melitus, diet karbohidrat yang berat ataupun perokok berat.

Kehilangan gigi merupakan salah satu perubahan jaringan rongga mulut. Jika gigi yang hilang tidak segera diganti dapat menimbulkan kesulitan bagi pasien sendiri, seperti mengunyah makanan, adanya gigi yang supraerupsi, miring atau bergeser. Penggantian gigi yang hilang dapat dilakukan dengan pembuatan gigi tiruan cekat atau gigi tiruan lepasan. ${ }^{6}$

Gigi tiruan lepasan adalah piranti yang dibuat untuk menggantikan gigi dan jaringan lunak disekitarnya yang hilang. Bahan yang paling sering digunakan untuk membuat basis gigi tiruan adalah yang terbuat dari bahan non-logam terutama polimer. ${ }^{7}$ Bahan polimer yang paling umum digunakan untuk pembuatan basis gigi tiruan adalah resin akrilik atau polimetilmetakrilat. ${ }^{8,9}$ Berdasarkan proses polimerisasi, resin akrilik diklasifikasikan sebagai resin akrilik polimerisasi sinar, resin akrilik polimersasi kimia, dan resin akrilik polimerisasi panas (RAPP). ${ }^{5,10}$

Resin akrilik polimerisasi panas digunakan dalam pembuatan hampir semua basis gigi tiruan. Sifat bahan basis gigi tiruan RAPP terbagi atas sifat mekanis, kemis dan biologis, serta fisis. Sifat biologis adalah sifat suatu bahan dalam interaksinya dengan makhluk hidup, seperti biokompatibilitas dan pembentukan koloni mikroflora. ${ }^{8}$

Denture stomatitis adalah penyakit yang paling sering diderita oleh pemakai gigi tiruan lepasan. Menurut Dwiatmoko S, dkk. (2011), 35-50\% pemakai gigi tiruan penuh lepasan dan $10-70 \%$ pemakai gigi tiruan sebagian lepasan menderita denture stomatitis. Faktor predisposisi terjadinya denture stomatitis antara lain kebersihan gigi tiruan yang buruk, gigi tiruan yang kurang pas, faktor sistemik, penggunaan antibiotik sembarangan, serta memakai gigi tiruan di malam hari menyebabkan penurunan laju aliran saliva di bawah permukaan gigi tiruan. ${ }^{11}$ Hasil penelitian Menroy dkk. (2005) melaporkan dari 50 orang yang menggunakan gigi tiruan yang mengalami denture stomatitis ditemukan hasil rata-rata pada membran mukosa Candida albicans sebanyak 66,7\%, Staphylococcus aureus dan Streptococcus mutans sebanyak 49,5\%. Candida albicans dapat ditemukan 
sebanyak $86 \%$ dari penderita denture stomatitis, bila dibandingkan dengan Staphylococcus aureus $84 \%$, dan Streptococcus mutans $16 \% .{ }^{12}$ Pada penelitian Koopmans dkk. (1988), mereka menemukan bahwa 69\% spesies cocci pada flora normal pengguna gigi tiruan dan 33\% spesies cocci pada penderita dentures stomatitis apabila dibandingkan dengan mikroflora yang lain. ${ }^{4}$

Beberapa penelitian telah dilakukan untuk melihat adanya efek penambahan agen antimikroba atau antijamur untuk resin akrilik. ${ }^{13}$ Penambahan nanopartikel $\mathrm{TiO}_{2}$ untuk RAPP dapat memberikan aktivitas antimikroba untuk basis resin akrilik. Di antara nanopartikel yang ada, titanium dioksida $\left(\mathrm{TiO}_{2}\right)$ sebagai bahan yang baik, karena sifat antibakteri telah dibuktikan dalam berbagai biomaterial. ${ }^{14,15}$

Nanopartikel $\mathrm{TiO}_{2}$ mempunyai karakteristik dengan spektrum antimikroba yang luas, biaya murah, tidak beracun, tidak berbau, tidak mengiritasi, tahan terhadap panas, dan resistensi kimia yang tinggi. ${ }^{15-18}$ Nanopartikel $\mathrm{TiO}_{2}$ mampu mengurangi kontaminan karena sifat fotokatalis. Fotokatalis akan aktif ketika terpapar oleh sinar ultraviolet (UV). Hal itu akan mengganggu stabilitas dinding sel dan membran sel yang menyebabkan kematian sel. ${ }^{19,20}$ Battin dkk. (2009) dan Foster (2011) melaporkan bahwa nanopartikel $\mathrm{TiO}_{2}$ memproduksi reactive oxygen species (ROS) didalam sel yang menyebabkan efek menghancurkan sel mikroba, oksidasi pada intraseluler coenzyme A dan peroksidasi dari beberapa lipid dapat menurunkan aktivitas pernafasan dan kemudian menyebabkan kematian sel. ${ }^{16}$

Menurut Xu dkk. (2002), dengan menambahkan bahan antimikroba untuk RAPP dapat mengurangi terjadinya kerusakan gigi dan jaringan periodontal. ${ }^{15}$ Selain itu, Matsunaga dkk. (1985) pertama kali melaporkan pengaruh antibakteri dengan fotokatalis $\mathrm{TiO}_{2}$ : kultur bakteri dengan menggunakan radiasi sinar ultraviolet selama 60-120 menit mempunyai reduksi signifikan dalam jumlah sel yang di kultur. ${ }^{21}$ Song R dkk. (2011) menunjukkan bahwa penambahan nanopartikel $\mathrm{TiO}_{2}$ meningkatkan sifat antimikroba pada RAPP. ${ }^{15}$ Titanium dioksida menunjukkan aktivitas penghambatan Staphylococcus aureus yang konsisten bila dikombinasikan dengan RAPP dan hasil terbaik dicapai pada konsentrasi $3 \% .22$

Tujuan penelitian ini adalah untuk mengetahui pengaruh penambahan titanium dioksida konsentrasi $2 \%$, $3 \%$ dan $4 \%$ pada bahan basis gigi tiruan resin akrilik polimerisasi panas terhadap jumlah Staphylococcus aureus dan Candida albicans.

\section{BAHAN DAN METODE}

Rancangan penelitian yang digunakan dalam penelitian ini adalah eksperimental laboratoris. Sampel dibuat dengan ukuran $10 \mathrm{~mm} \times 10 \mathrm{~mm}$ x $1 \mathrm{~mm}$. Jumlah keseluruhan sampel adalah 48 sampel yang terdiri dari 24 sampel uji jumlah Staphylococcus aureus dan 24 sampel uji jumlah Candida albicans, kemudian sampel dibagi dalam 4 kelompok (kelompok A: RAPP tanpa penambahan $\mathrm{TiO}_{2}$, kelompok B: RAPP dengan penambahan nanopartikel $\mathrm{TiO}_{2}$ konsentrasi $2 \%$, kelompok C: RAPP dengan penambahan nanopartikel $\mathrm{TiO}_{2}$ konsentrasi 3\%, dan kelompok D: RAPP dengan penambahan nanopartikel $\mathrm{TiO}_{2}$ konsentrasi $4 \%$ ).

Pengisian akrilik pada mold terdiri dari 6 tahap. Pertama, pengisian kuvet dengan RAPP tanpa dan dengan penambahan $\mathrm{TiO}_{2}$ konsentrasi $2 \%$, 3\% dan $4 \%$. (a) RAPP tanpa bahan penguat nanopartikel $\mathrm{TiO}_{2}$. Polimer dan monomer disiapkan di dalam pot porselen dengan perbandingan $2 \mathrm{~g}$ bubuk : $1 \mathrm{ml}$ cairan lalu diaduk hingga homogen. (b) RAPP dengan penambahan nanopartikel $\mathrm{TiO}_{2}$ konsentrasi $2 \%$. Nanopartikel $\mathrm{TiO}_{2}$ ditimbang sebanyak $0,18 \mathrm{~g}$ untuk 1 buah kuvet yang terdiri dari 10 mold sampel. Perhitungan tersebut setara dengan $2 \%$ dari total berat polimer dan monomer. Maka perbandingan $\mathrm{TiO}_{2}$ : polimer : monomer untuk pengisian mold adalah 0,18 g : 5,82 g : $3 \mathrm{ml}$. (c) RAPP dengan penambahan nanopartikel $\mathrm{TiO}_{2}$ konsentrasi $3 \%$. Nanopartikel $\mathrm{TiO}_{2}$ ditimbang sebanyak 0,27 g untuk 1 buah kuvet yang terdiri dari 10 mold sampel. Perhitungan tersebut setara dengan 3\% dari total berat polimer dan monomer. Maka perbandingan $\mathrm{TiO}_{2}$ : polimer : monomer untuk pengisian mold adalah $0,27 \mathrm{~g}: 5,73 \mathrm{~g}: 3 \mathrm{ml}$. (d) RAPP dengan penambahan nanopartikel $\mathrm{TiO}_{2}$ konsentrasi 4\%. Nanopartikel $\mathrm{TiO}_{2}$ ditimbang sebanyak $0,36 \mathrm{~g}$ untuk 1 buah kuvet yang terdiri dari 10 mold sampel. Perhitungan tersebut setara dengan $4 \%$ dari total berat polimer dan monomer. Maka perbandingan $\mathrm{TiO}_{2}$ : polimer : monomer untuk pengisian mold adalah $0,36 \mathrm{~g}$ : $5,64 \mathrm{~g}: 3 \mathrm{ml}$ di dalam pot akrilik dan diaduk menggunakan spatula semen hingga homogen.

Kedua, nanopartikel $\mathrm{TiO}_{2}$ dicampurkan ke dalam monomer di dalam tabung Erlenmeyer, kemudian dimasukkan ke dalam sonikator selama 30 menit. Setelah itu campurkan monomer yang mengandung nanopartikel $\mathrm{TiO}_{2}$ dengan polimer lalu diaduk perlahan dengan spatula semen sampai monomer dan polimer tercampur baik dan homogen. Adonan didiamkan hingga dough stage dan tidak menempel pada dinding pot pengaduk akrilik.

Ketiga, setelah adonan mencapai fase dough stage kemudian adonan dimasukkan ke dalam mold. Keempat, resin akrilik polimerisasi panas yang ditambah nanopartikel $\mathrm{TiO}_{2}$ ditutup dengan plastik selopan kemudian kuvet atas dipasangkan, kuvet ditekan perlahan-lahan dengan pres hidrolik mencapai 1000 psi, lalu kuvet dibuka. Akrilik yang berlebih dipotong dengan lekron. Kelima, kuvet ditutup kembali, kemudian ditekan 
dengan tekanan 1500 psi. Keenam, baut kuvet dipasang untuk mempertahankan kuvet atas dan kuvet bawah agar beradaptasi dengan baik kemudian dibiarkan selama 15 menit. Kuvet dimasukkan ke dalam waterbath, mulamula suhu dan waktu curing diatur yaitu $70^{\circ} \mathrm{C}$ dibiarkan selama 30 menit, kemudian suhu dan waktu curing dinaikkan menjadi $100^{\circ} \mathrm{C}$ dibiarkan selama 90 menit. Kuvet dibiarkan di dalam waterbath selama 30 menit untuk proses pendinginan. Setelah itu kuvet diletakkan di bawah air mengalir selama 15 menit dan dibiarkan dingin hingga mencapai suhu kamar. Sampel dikeluarkan dari kuvet, kemudian dirapikan untuk menghilangkan bagian yang tajam dengan menggunakan bur fraser kemudian sampel dihaluskan permukaannya dengan kertas pasir ukuran 500 dan 800 .

Penentuan jumlah Staphylococcus aureus dan Candida albicans sebagai berikut. Pertama, seka sampel RAPP dengan menggunakan cotton bud steril lalu dimasukkan ke dalam tabung reaksi yang berisi $10 \mathrm{ml}$ PBS. Kedua, ambil sekitar $0,01 \mathrm{ml}$ cairan dari dalam tabung reaksi yang berisi PBS dengan menggunakan mikropipet dan disemprotkan ke dalam cawan petri, lalu tuangkan $15 \mathrm{ml}$ Manitol Salt Agar (MSA) untuk uji Staphylococcus aureus dan Sabouraud's Dextrose agar (SDA) untuk uji Candida albicans ke dalam cawan petri dan menyebarkan cairan tersebut secara merata. Ketiga, inkubasi pada suhu $37^{\circ} \mathrm{C}$ selama 24 jam untuk uji Staphylococcus aureus dan 48 jam untuk uji Candida albicans. Keempat, penghitungan jumlah koloni dilakukan dengan menggunakan colony counter dalam satuan CFU/ml. Analisis data dilakukan dengan uji Univarian, uji Anova satu arah, dan uji LSD.

\section{HASIL}

Hasil penelitian ini menunjukkan bahwa ada pengaruh penambahan nanopartikel $\mathrm{TiO}_{2}$ terhadap jumlah Staphylococcus aureus dilihat dari nilai $\mathrm{p}=0,0001$ $(\mathrm{p}<0,05)$ dan Candida albicans dilihat dari nilai $\mathrm{p}=0,0001$ $(\mathrm{p}<0,05)$ yang terlihat pada Tabel 1.

Berdasarkan hasil uji Anova satu arah terlihat adanya pengaruh penambahan titanium dioksida konsentrasi $2 \%$, $3 \%$ dan $4 \%$ pada bahan basis gigi tiruan RAPP terhadap jumlah Staphylococcus aureus dan Candida albicans yang dianalisis dengan menggunakan uji Anova satu arah dan diperoleh nilai $\mathrm{p}=0,0001(\mathrm{p}>0,05)$ seperti pada Tabel 2 dan Tabel 3).

Hasil penelitian menunjukkan bahwa ada pengaruh penambahan nanopartikel $\mathrm{TiO}_{2}$ terhadap jumlah Staphylococcus aureus dan Candida albicans pada bahan basis gigi tiruan RAPP $(\mathrm{p}=0,0001)$. Dari hasil uji LSD didapatkan bahwa pada tingkat signifikansi jumlah Staphylococcus aureus pada bahan basis gigi tiruan RAPP terdapat perbedaan pengaruh yang signifikan $(\mathrm{p}<0,05)$. Begitu juga dengan tingkat signifikansi jumlah Candida albicans pada bahan basis gigi tiruan RAPP, terdapat perbedaan pengaruh yang signifikan $(p<0,05)$ (Tabel 4) dan (Tabel 5).

Tabel 1. Jumlah Staphylococcus aureus dan Candida albicans pada bahan basis gigi tiruan resin akrilik polimerisasi panas dengan penambahan Titanium dioksida $\left(\mathrm{TiO}_{2}\right)$ konsentrasi $2 \%, 3 \%$ dan $4 \%$

\begin{tabular}{|c|c|c|c|c|c|c|c|c|}
\hline \multirow{4}{*}{ Sampel } & \multicolumn{8}{|c|}{ Jumlah Staphylococcus aureus dan Candida albicans (CFU/ml) } \\
\hline & \multirow{2}{*}{\multicolumn{2}{|c|}{$\begin{array}{c}\text { Tanpa Penambahan } \mathrm{TiO}_{2} \\
\text { Kontrol }\end{array}$}} & \multicolumn{6}{|c|}{ Penambahan $\mathrm{TiO}_{2}$} \\
\hline & & & \multicolumn{2}{|c|}{$2 \%$} & \multicolumn{2}{|c|}{$3 \%$} & \multicolumn{2}{|c|}{$4 \%$} \\
\hline & Sa (A1) & $\begin{array}{c}\text { Ca } \\
\text { (A2) }\end{array}$ & $\begin{array}{c}\text { Sa } \\
\text { (B1) }\end{array}$ & $\begin{array}{c}\mathrm{Ca} \\
(\mathrm{B} 2)\end{array}$ & $\begin{array}{c}\text { Sa } \\
(\mathrm{C} 1)\end{array}$ & $\begin{array}{c}\mathrm{Ca} \\
(\mathrm{C} 2)\end{array}$ & $\begin{array}{c}\text { Sa } \\
\text { (D1) }\end{array}$ & $\begin{array}{c}\text { Ca } \\
\text { (D2) }\end{array}$ \\
\hline 1 & $226^{*}$ & 256 & $162 * *$ & $20 *$ & $79 * *$ & $18 * *$ & 8 & $2 *$ \\
\hline 2 & 265 & 265 & 139 & $28 * *$ & 28 & 13 & $4 *$ & $5 * *$ \\
\hline 3 & 235 & 252 & 154 & 27 & 25 & 12 & 16 & 4 \\
\hline 4 & 232 & $186^{*}$ & 161 & $20 *$ & 46 & 16 & $18 * *$ & $5 * *$ \\
\hline 5 & $282 * *$ & $271 * *$ & 131 & 21 & 48 & 13 & 7 & 4 \\
\hline 6 & 240 & 201 & $106^{*}$ & 25 & $21 *$ & $10 *$ & 10 & $2 *$ \\
\hline $\bar{X} \pm \mathrm{SD}$ & $\begin{array}{c}246,667 \\
\pm \\
21,942\end{array}$ & $\begin{array}{l}238,500 \\
\pm \\
35,804\end{array}$ & $\begin{array}{c}142,167 \\
\pm \\
21,591\end{array}$ & $\begin{array}{l}23,500 \\
\quad \pm \\
3,619\end{array}$ & $\begin{array}{c}41,167 \\
\pm \\
21,646\end{array}$ & $\begin{array}{l}13,667 \\
\pm \\
2,875\end{array}$ & $\begin{array}{l}10,500 \\
\quad \pm \\
5,431\end{array}$ & $\begin{array}{l}3,667 \\
\quad \pm \\
1,366\end{array}$ \\
\hline
\end{tabular}

\footnotetext{
*nilai terkecil
}

**nilai terbesar 
Tabel 2. Pengaruh penambahan Titanium dioksida $\left(\mathrm{TiO}_{2}\right)$ konsentrasi 2\%, 3\% dan 4\% terhadap jumlah Staphylococcus aureus pada bahan basis gigi tiruan resin akrilik polimerisasi panas

\begin{tabular}{cccc}
\hline & \multicolumn{3}{c}{$\sum$ S aureus } \\
Kelompok & $\mathrm{N}$ & $\bar{X} \pm$ Standar deviasi & $\mathrm{p}$ \\
& & $246,667 \pm 21,946$ & \\
A1 & 6 & $142,167 \pm 21,591$ & $0,0001^{*}$ \\
C1 & 6 & $41,167 \pm 21,646$ & \\
D1 & 6 & $10,500 \pm 5,431$ & \\
\hline
\end{tabular}

*terdapat perbedaan yang signifikan $(\mathrm{p}<0,05)$

Tabel 3. Pengaruh penambahan Titanium dioksida $\left(\mathrm{TiO}_{2}\right)$ konsentrasi 2\%, 3\% dan 4\% terhadap jumlah Candida albicans pada bahan basis gigi tiruan resin akrilik polimerisasi panas

\begin{tabular}{|c|c|c|c|}
\hline \multirow{2}{*}{ Kelompok } & \multicolumn{2}{|r|}{$\sum C$ albicans } & \multirow{2}{*}{$\mathrm{p}$} \\
\hline & iv & $\bar{X} \pm$ Standar deviasi & \\
\hline $\mathrm{A} 2$ & 6 & $238,500 \pm 21,591$ & \\
\hline \multirow[t]{2}{*}{ B2 } & 6 & $23,500 \pm 3,619$ & \\
\hline & & & $0,0001 *$ \\
\hline $\mathrm{C} 2$ & 6 & $13,667 \pm 2,875$ & \\
\hline D2 & 6 & $3,667 \pm 1,366$ & \\
\hline
\end{tabular}

*terdapat perbedaan yang signifikan $(\mathrm{p}<0,05)$

Tabel 4. Perbedaan pengaruh penambahan Titanium dioksida $\left(\mathrm{TiO}_{2}\right)$ konsentrasi $2 \%, 3 \%$ dan $4 \%$ terhadap jumlah Staphylococcus aureus pada bahan basis gigi tiruan resin akrilik polimerisasi panas

\begin{tabular}{cccc}
\hline \multicolumn{2}{r}{ Kelompok } & Rata-rata perbedaan & $\mathrm{p}$ \\
\hline \multirow{3}{*}{ B1 } & C1 & 101,000 & $0,0001^{*}$ \\
& D1 & 131,667 & $0,0001^{*}$ \\
C1 & B1 & 101,000 & $0,0001^{*}$ \\
& D1 & 30,667 & $0,011^{*}$ \\
D1 & B1 & 131,667 & $0,0001^{*}$ \\
& C1 & 30,667 & $0,011^{*}$ \\
\hline
\end{tabular}

*terdapat perbedaan yang signifikan $(\mathrm{p}<0,05)$
Tabel 5. Perbedaan pengaruh penambahan Titanium dioksida $\left(\mathrm{TiO}_{2}\right)$ konsentrasi 2\%, 3\% dan 4\% terhadap jumlah Candida albicans pada bahan basis gigi tiruan resin akrilik polimerisasi panas

\begin{tabular}{cccc}
\hline \multicolumn{2}{r}{ Kelompok } & Rata-rata perbedaan & $\mathrm{p}$ \\
\hline \multirow{2}{*}{ B2 } & C2 & 9,833 & $0,0001^{*}$ \\
& D2 & 19,833 & $0,0001^{*}$ \\
& B2 2 & 9,833 & $0,0001^{*}$ \\
& D2 & 10,000 & $0,0001^{*}$ \\
D2 & B2 & 19,833 & $0,0001^{*}$ \\
& C2 & 10,000 & $0,0001^{*}$ \\
\hline
\end{tabular}

*terdapat perbedaan yang signifikan $(\mathrm{p}<0,05)$

\section{PEMBAHASAN}

Hasil penelitian ini diperoleh jumlah Staphylococcus aureus dan Candida albicans yang bervariasi. Hal ini disebabkan karena adanya efek yang berbeda pada setiap konsentrasi nanopartikel $\mathrm{TiO}_{2}$ terhadap penurunan jumlah Staphylococcus aureus dan Candida albicans akibat kemampuan setiap konsentrasi untuk menurunkan jumlah Staphylococcus aureus dan Candida albicans. ${ }^{15}$ Tabung reaksi yang berisi larutan PBS dan cotton swab tempat melekatnya Staphylococcus aureus dan Candida albicans digetarkan secara manual sehingga menyebabkan Staphylococcus aureus dan Candida albicans yang melekat pada cotton swab tidak terlepas secara merata.

Berdasarkan penelitian Song dkk. (2011) disimpulkan bahwa penambahan nanopartikel $\mathrm{TiO}_{2}$ dapat meningkatkan sifat antibakteri pada bahan basis gigi tiruan resin akrilik. ${ }^{15}$ Pada penelitian ini, penurunan jumlah Staphylococcus aureus dan Candida albicans terbanyak adalah pada konsentrasi 4\%, hal ini dikarenakan semakin tinggi konsentrasi $\mathrm{TiO}_{2}$ maka semakin sedikit pula jumlah Staphylococcus aureus dan Candida albicans yang tersisa pada cawan petri. Selain itu, nanopartikel $\mathrm{TiO}_{2}$ mempunyai sifat self-cleansing yaitu daya membersihkan sendiri yang berfungsi untuk menghilangkan bau, zat organik dan anorganik, serta sifat self-sterilizing yang dapat membersihkan mikroba. Dengan demikian, kinerja katalisis $\mathrm{TiO}_{2}$ dapat digunakan sebagai antimikroba. ${ }^{23}$

Pada kelompok bahan basis gigi tiruan RAPP yang ditambah nanopartikel $\mathrm{TiO}_{2}$ konsentrasi 2\%, 3\% dan 4\% terhadap jumlah Staphylococcus aureus dan Candida albicans menunjukkan adanya pengaruh yang signifikan. Hal ini terlihat dengan berkurangnya jumlah Staphylo- 
coccus aureus dan Candida albicans pada cawan petri. Nanopartikel $\mathrm{TiO}_{2}$ memiliki aktivitas penghambatan terhadap Staphylococcus aureus dan Candida albicans saat dicampur dengan bahan basis gigi tiruan RAPP. Aktivitas fotokatalis dapat menghambat pertumbuhan Staphylococcus aureus dan Candida albicans pada gigi tiruan. ${ }^{22}$ Nanopartikel $\mathrm{TiO}_{2}$ mampu mengurangi kontaminan karena sifat fotokatalis. Fotokatalis akan aktif ketika terpapar oleh sinar ultraviolet. Hal itu akan mengganggu stabilitas dinding sel dan membran sel sehingga menyebabkan kematian sel. ${ }^{19,20}$ Telah dilaporkan bahwa, nanopartikel $\mathrm{TiO}_{2}$ memproduksi reactive oxygen species (ROS) di dalam sel mikroba menyebabkan efek menghancurkan sel mikroba melalui oksidasi pada intraseluler coenzyme A dan peroksidasi dari beberapa lipid sehingga dapat menurunkan aktivitas pernafasan dan kemudian menyebabkan kematian sel mikroba. ${ }^{16}$

Pada penelitian ini, Staphylococcus aureus lebih resisten dibandingkan dengan Candida albicans. Hal ini disebabkan karena Staphylococcus aureus mampu memproduksi staphyloxantin yaitu sebuah carotenoid pigment yang berwarna keemasan yang berperan dalam virulensi bakteri. Komponen ini merupakan antioksidan bakterial yang dapat dipergunakan oleh bakteri untuk menghindari pengaruh reactive oxygen species (ROS) yang merupakan salah satu sistem imunitas hasil fagositosis saat membunuh bakteri. ${ }^{24}$

\section{KESIMPULAN}

Berdasarkan hasil penelitian diatas, dapat disimpulkan bahwa penambahan nanopartikel $\mathrm{TiO}_{2}$ konsentrasi 2\%,3\% dan 4\% dapat menurunkan jumlah Staphylococcus aureus dan Candida albicans pada bahan basis gigi tiruan RAPP, dan konsentrasi yang dapat menurunkan jumlah terbanyak adalah pada nanopartikel $\mathrm{TiO}_{2}$ konsentrasi $4 \%$.

\section{KONFLIK KEPENTINGAN}

Penulis menyatakan tidak ada konflik kepentingan di dalam penelitian ini.

\section{DAFTAR PUSTAKA}

1. Razak PA, Richard KMJ, Thankachan RP, Hafiz KAA, Kumar KN, Sameer KM. Geriatric oral health: a review article. J Int Oral Health. 2014;6(6):110-6.

2. Komariah, Sjam R. Kolonisasi Candida dalam rongga mulut. Majalah Kedokteran FK UKI 2012;28(1):39-47.

3. Ritonga PWU. 2015. Pengaruh desinfeksi gigi tiruan dengan energy microwave dan larutan kumur klorheksidin terhadap jumlah Candida albicans pada pemakai gigi tiruan penuh resin akrilik polimerisasi panas. Tesis. FKG USU: Medan.

4. Koopmans ASF, Kippuw n, Gaaff JD. Bacterial involvement in denture-induced stomatitis. J Dent Res. 1988;67(9):1246-50.

5. Minasari, Unita L. Efektifitas ekstrak temulawak (Curcuma xanthorrizaroxb) terhadap pertumbuhan Candida albicans dan Staphylococcus aureus dari denture stomatitis. Dept Biologi Oral FKG USU 2017;1-7.

6. Rahmayani L, Herwanda, Idawani M. Perilaku pemakai gigi tiruan terhadap pemeliharaan kebersihan gigi tiruan lepasan. J PDGI. 2013;62(3): 83-8.

7. Rueggeberg FA. Dental materials for complete denture. In: Rahn AO, et al. eds. Textbook of complete denture, $6^{\text {th }}$ ed., USA: People's Medical Publishing House, 2006;8-10.

8. McCabe JF, Walls AWG. Applied dental materials. $9^{\text {th }}$ ed., London: Blackwell, 2008;110-23.

9. Ferracane JL. Materials in dentistry principles and applications. $2^{\text {nd }}$ ed., USA: Lippincott Williams \& Wilkins, 2001;255-78.

10. Manappallil JJ. Basic dental materials. $3^{\text {rd }}$ ed., New Delhi: Jaypee Brothers Medical Publishers (P), 1998; 94-123.

11. Dwiatmoko S, Kristiana D. Pengaruh komunikasi kesehatan secara lisan dan tulisan terhadap pengetahuan, sikap dan kebersihan gigi tiruan para pemakai gigi tiruan lepasan. Dentika Dent J. 2011; 16(1):14-7.

12. Baena-Monroy T, Moreno-Maldonado V, FrancoMartinez F, Aldape-Barrios B, Quindos G, SanchezVargas LO. Candida albicans, Staphylococcus aureus and Streptococcus mutans colonization in patients wearing dental prosthesis. Med Patol Oral Cir Bucal. 2005;10:27-30.

13. Kuroki K, Hayashi T, Sato K, Asai T, Okano M, Kominami Y, et al. Effect of self-cured acrylic resin added with an inorganic antibacterial agent on Streptococcus mutans. Dent Materials J. 2010; 29:277-85.

14. Sodagar A, Khalil S, Kassasee MZ, Shahroudi AS, Pourakbari B, Bahador A. Antimicrobial properties of poly (methyl methacrylate) acrylic resin incorporated and titanium dioxide nanoparticles on cariogenic bacteria. J Orthod Sci. 2016;5(1):7-13.

15. Song R, Jiao X, Lin L. Improvement of mechanical and antimicrobial properties of denture base resin by nano-titanium dioxide and nano-silicon dioxide particles. Pigment \& Resin Technology. 2011;40(6): 393-8.

16. Haghighi F, Mohammadi SR, Mohammadi P, Hosseinkhani S, Shidpour R. Antifungal acivity of $\mathrm{TiO} 2$ nanoparticles and EDTA on Candida albicans biofilms. Infect Epidemiol Med. 2013;1(1):33-8.

17. Gao Y, Masuda Y, Seo WS, Ohta H, Koumoto K. $\mathrm{TiO} 2$ nanoparticles prepared using an aqueous 
peroxotitanate solution. Ceramics Int. 2004; 30:1365-8.

18. Shibata T, Hamada N, Kimoto K, Sawada T, Sawada $\mathrm{T}$, Kumada $\mathrm{H}$, et al. Antifungal effect of acrylic resin containing apatite-coated $\mathrm{TiO} 2$ photocatalyst. Dent Materials J. 2007;26(3):43-4.

19. Badrodin M. Pemanfaatan nanopartikel perakdan titanium sebagai antikontaminan dalam kultur jaringan tumbuhan. Skripsi. Yogyakarta: Fakultas Biologi UGM, 2015.

20. Safavi K. Evaluation of using nanomaterial in tissue culture media and biological avtivity. Proceding International Conference on Ecological, Environmental and Biological Sciences $2^{\text {nd }}$ in Bali (Indonesia):5-8.

21. Yang JY, Kim HJ, Chung CH. Photocatalytic antifungal activity against Candida albicans by $\mathrm{TiO}_{2}$ coated acrylic resin denture base. J Korean Acad Prost. 2006;44(3):284-94.

22. Anehosur GV, Kulkarni RD, Naik MG, Nadiger RK. Synthesis and determination of antimicrobial activity of visible light activated $\mathrm{TiO}_{2}$ nanoparticles with polymethyl methacrylate denture base resin against Staphylococcus aureus. J Gerontol Geriat Res. 2012; 1(1):1-8.

23. Fujishima A, Rao TN, Tryk DA. Titanium dioxide photocatalysis. J Photochemistry and Photobiology. 2000;1:1-21.

24. Murwani S, Qosimah D, Amri IA. Penyakit bakterial pada ternak hewan besar dan unggas. $1^{\text {st }}$ ed., Malang: UB Press, 2017: 265. 